\title{
THE NEW SILK ROAD - ANALYSIS OF THE POTENTIAL OF NEW EURASIAN TRANSPORT CORRIDORS
}

\author{
Joanicjusz Nazarko' ${ }^{1}$, Katarzyna Anna Kuźmicz ${ }^{2}$, Katarzyna Czerewacz-Filipowicz ${ }^{3}$ \\ Faculty of Management, Bialystok University of Technology, Wiejska 45A, Bialystok, Poland \\ E-mails: ${ }^{1}$.nazarko@pb.edu.pl; ${ }^{2}$ k.kuzmicz@pb.edu.pl (corresponding author); ${ }^{3}$ k.czerewacz@pb.edu.pl
}

\begin{abstract}
The objective of this paper is to investigate the potential of the Chinese initiative The New Silk Route (NSR) comprising two transport routes: railway and maritime, linking Europe and Asia. In the paper the NSR was analysed from the perspective of: potential benefits from countries' participation in NSR and challenges that NSR will have to face to become a well performing transport corridor. The authors point out that the NSR is going to be a logistic corridor that is to influence transport and supply chains and determine the position of participating countries in international division of labour.
\end{abstract}

Keywords: One Belt One Road, New Silk Road, transport corridor, logistic corridor, global supply chains, international trade.

JEL Classification: R42; L91; L92; F15.

\section{Introduction}

The Chinese Dream to reclaim national pride and enhance Chinese role in world economy is embodied in the concept of One Belt, One Road (OBOR). It is also called the New Silk Road (NSR) and embraces two routes: rail and maritime that are going to link Asia with Europe (Fig. 1). In particular it is going to connect China with Asia, Europe and Africa. It embraces multidimensional strategy which, if successfully implemented, is going to boost international trade and significantly influence global supply chains and transport in particular. NJS providing intercontinental transport comprising a central component of contemporary supply chain management (Rushton et al. 2010) should be perceived as a crucial initiative changing logistics worldwide. The infrastructural development accompanying this initiative will be also a vital point in logistics development of the countries on the New Silk Road. It will also change international economic relations and create more economic dependencies. In this way it a pivotal issue in political terms. The importance of the initiative can be stressed by the fact that it will affect about 65 countries, 4.4 billion people and $63 \%$ of global population (Centre for Research and Globalisation 2015).

The OBOR concept has three pillars: first spreading economic development around the world through infrastructure investment and new trade routes, second - creating interdependence between China and other countries and regions via global partnerships networks, third - focusing on Asia as a part of a new "neighbourhood diplomacy" (Lo 2015). Important aspect is also to increase renminbi internationalisation by encouraging its usage in financial transactions (Lo 2015).

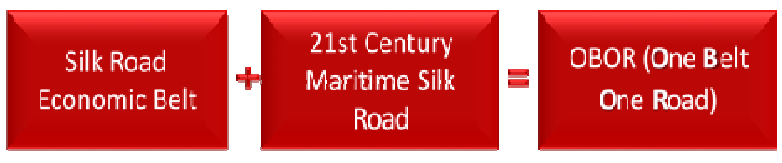

Fig. 1. The OBOR concept

(Source: elaborated by the authors)

\section{Variants of the route}

The New Silk Road comprises a combination of routes that will include the existing ones. Emerson and Vinokurov stress that the four major economies of the EU, Russia, China and India are highly interested in developing trade flows between each other (Emerson, Vinokurov 2009). They present a map of Eurasian transport corridors (Fig. 2).

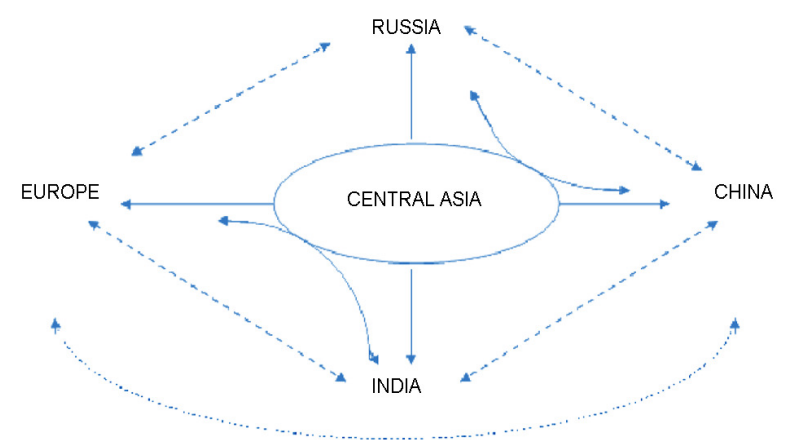

Fig. 2. Schematic map of Eurasian transport corridors (Source: Emerson, Vinokurov 2009) 
They indicate diagonal routes going around Central Asia: west-north (EU-Russia, by land), north-east (Russia-China by land), west-south (EUIndia by land and sea), south-east (India-China by sea), west-south-east (EU-China by sea). They also point to vertical and horizontal connections running from Central Asia, like: west-east (EUCentral Asia-China) or north-south (Russia-Central Asia-India) and some diagonal routes through Central Asia: north-east to south west (West China to the Middle East), north-west to south-east (Northern Europe to India). All the initiatives supporting the transport needs of EU, Russia, China and India and all the stakeholders participating in these markets receive great attention.

The NSR is a not first but probably the most likely to fulfil concept of an Eurasian transport corridor. The previous concepts of EU like TRACEA or Asian undertaking called CAREC were criticised as not well coordinated (Emerson, Vinokurov 2009). There are many variants of the New Silk Route but they are not exclusive. They can complement each other. The general idea of the NSR is presented in the Figure 3.

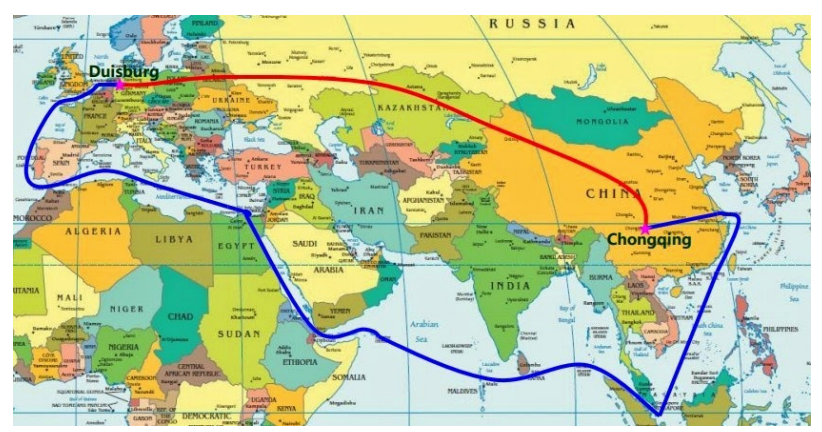

Fig. 3. The idea of the New Silk Route (Source: SeaNews Turkey 2014)

There are three main alternative corridors along the NSR well summarised by Sahbaz (2014):

\section{The Northern Corridor:}

This corridor uses the Russian Trans-Siberian Railway line, starting in Kazakhstan and connecting to Russia. Passing through the Russian mainland, the Northern Corridor reaches Belarus and Poland as a gate to Europe. This corridor is currently operational. It also crosses through the least number of countries, hence involves least number of border crossings, amongst the three alternatives. This variant seems to be predominant.

\section{The Southern Corridor:}

It starts from Kazakhstan, passes through Turkmenistan or Kyrgyzstan and Tajikistan to Iran. Through Iran, it reaches Turkey and then finally connects with Europe. The main disadvantages of this corridor are the high number of border crossings and political instability in the region.

\section{The Middle Corridor:}

It crosses Kazakhstan to reach the Kazakh Caspian port of Aktau. By sea connection, it reaches the newly built Azeri port of Alat. The corridor then passes through the South Caucasus and reaches Europe via Turkey. The Middle Corridor is a politically viable alternative with the countries en route having relatively Western-friendly regimes. The main disadvantages are inter-modality at the Caspian crossing and the frozen conflicts in the Caucasus region.

\section{The global dimension of the New Silk Road}

Over the last 25 years, the countries of Asia and Eurasia have been experiencing a real eruption of integration initiatives both in the form of preferential trade agreements (PTAs), regional trade agreements (RTAs) and other concepts of regional integration (RIAs) difficult to classify. This involves both the desire for economic development, improving the position of individual countries in the international division of labour and the fact that many East Asian countries use trade as an engine to growth.

Theoretically, there are two drivers of integration trends: the domino effect and competitive regionalism (or regionalism as insurance) (Bonapace, Mikic 2007). On the one hand, the New Silk Road is going to lead to trade creation and trade diversion effects (El-Agraa 1999) and therefore many countries are afraid that non-participation in the NSR will expose them to the effects of discrimination (Baldwin 1993). Taking into account the fact that the New Silk Road is formed by China and the European Union, that is, the most important economic partners of most of the world countries, the fears are fully justified. On the other hand, it is difficult to deny that the NSR is an element of international competition. It seems to be the initiative that is competitive against e.g. The Trans-Pacific Partnership (TPP) being aimed at protecting the participants from the effects of discriminatory agreements concluded by the USA.

Since the collapse of the USSR several competing concepts of rebuilding trade and transportation arteries between Europe and Asia (China) have been established. The initiative was the European Union's (TRACEA), the New Eurasian Land Transport Initiative (NELTI) (Vinokurov, Libman 2012) and in 2010 even the USA's. But only the Chinese concept of the Silk Road Economic Belt, as part of China's broader "One Belt One Road" 
initiative has a chance of implementation (Starr et al. 2015). Chinese vision has a strongly enough impact that other Asian and Eurasian concepts are perceived by its prism. Eurasian Economic Union is seen today through the prism of the benefits from the Customs Union and the absence of customs borders which facilitates transport of goods between China and the EU. Some new opportunities are opening up in relations between the countries of the EU and ASEAN and SAADC (The European Union Chamber of Commerce in China).

The concept of the New Silk Road forces the reorientation of economic policy in many countries of Europe and Asia as it will cause some growing volumes on the over-land links. This in turn will help cut transport costs and speed transport and thus raise the competitiveness of the trade route and attract transport and logistics firms to make further use of these routes.

The New Silk Road involves both the route using maritime transport and railway overland route. The development of the railway infrastructure is a challenge but in this case you can expect a variety of spillover effects.

The researches on the relationship between the development of infrastructure and economic development conducted in China show that the mere creation of transport infrastructure is not enough to achieve positive spill-over. Yu, de Jong, Storm, Mi (Yu et al. 2013) show that, in the case of the use of this instrument as a driving factor which had had to lead to economic development, different effects can be observed. At the national level, positive spillover is being observed, but in the context of individual regions the results are different. In some regions, negative spillover was observed throughout the part or the whole research period, because the final word in this matter rested in the migration of production factors in China.

The railway route of the New Silk Road is to have a positive impact on the economic development of countries and regions participating in it, and through the spillover effect it is likely to spread into different industries and areas geographically adjacent.

China has already made a number of institutional steps creating the Asian Infrastructure Investment Bank. It has become a member of the European Bank for Reconstruction and Development to jointly implement infrastructure investments in Central Asia to eastern Europe and North Africa (Williams 2015; The European Union Chamber of Commerce in China 2015).

China will only be a financial donor and not recipient with EBRD. However, China may benefit indirectly through EBRD projects in countries such as Kazakhstan which overlap with the "One Belt, One Road" initiative. China is also going to explore the possibilities of joining the EBRD and building up synergies between the New Silk Road Initiative and the Junker Plan (EUCTP II 2015).

\section{The Chinese economic policy}

NSR should be perceived as an initiative changing current international economy. Since about a year it is treated as a key, universal tool of Chinese foreign policy. Almost all actions of China in international relations are connected with this idea which is going to serve to Chinese economic and geoeconomic expansion and conscious and systematic shaping of international trade relations.

At the same time NSR concept is the answer to domestic economic problems concerning societal inequalities, underdevelopment of Western provinces, insufficient domestic demand and, in consequence, excessive dependency from world economic situation and the risk of the so called: Middle income trap.

The economic policy of the Chinese government is determined through the premises of the 5year plans, the decisions of the Communist Party of China (CPC) and the world economic situation, which in fact means global financial crisis from 2008 and decrease in global demand (Informator Ekonomiczny o Krajach Świata 2016).

Starting from the 12. 5-year plan (2011-2015) with the economic transformation and the rule of scientific development a big stress was put on the harmonious human development (Embassy of the Republic of Poland in Beijing 2016). This tendency has prevailed in the current 13. 5-year plan for the time span 2016-2020 (Embassy of the Republic of Poland in Beijing 2016). The existing societal inequalities are going to be reduced among others by the annual minimal wage rise and multidimensional broadening of social security benefits. This means building a strong domestic market, increasing domestic demand for both domestic and imported goods. The Chinese economic strategy also involves a set of infrastructural investments and creating new communication and trade routes.

The priorities of the Chinese foreign and domestic economic policy are a signal for economic partners, that the policy of opening will be continued. Therefore the forthcoming years will be important for those functioning on the Chinese market and those who want to make a start in this economic area. 
The NSR is perceived as an integrative initiative. Similarly like in other such initiatives of economic international integration, the effects of creation and shifts in trade will occur for the benefit of the countries participating and for the loos of the countries which will stay outside. The other issue of this integration is the case of legal regulations, standardisation and liberalisation of regulations making smooth operation of the Route possible.

The European Union (28) is the largest trade partner of China with $14.3 \%$ of the volume of the trade turnover of this country. China is the second largest trade partner of EU (28) with almost 14\% of its turnover. The dynamics of the rise of the economic relations is spectacular. Looking towards the future it can be stated that the position of EU in the international division of labour will depend to the big extend on the relations with China (European Commission 2016; IMF 2016).

The NSR is based on two modes of transport: rail and sea. Currently rail transport covers a little part of trade turnover between China and EU(28) only about $3-4 \%$. Much more developed is transport through the sea way. This part of the NSR is planned to broaden Chinese relations not only with Europe but also with the Middle East. Both of the routes should be treated rather as complementary than as competitive. Sea transport from China to Europe takes about $30-40$ day, which is too long for many goods and rail transport needs only 11-14 days and is much cheaper than air transport.

According to South China Morning Post, the rail part of the NSR will cross the border of the UE in Poland and its route will pass through Lodz, Hamburg, Duisburg, Pardubitz and even further (Yang 2014). A crucial factor is that Germany, the Netherlands and Great Britain are the most important trade partners of China in Europe.

\section{Trade as a driving factor}

The European Union is the most important trading partner for China, China is the second partner for the EU after the United States. However, bilateral trade has increased dramatically in recent years. China is the largest supplier of goods to the EU market. The EU records a significant trade deficit with China. The EU shows global and Asian value chains as the main causes of this phenomenon, but in part is also due to remaining market access barriers in China (European Commission 2016).

The structure of mutual trade seems to be responsible for that, too (Figs 4, 5). The EU imports from China are dominated by industrial and con- sumer goods: machinery and equipment, footwear and clothing, furniture and lamps, and toys. The EU exports to China are concentrated on machinery and equipment, motor vehicles, aircraft, and chemicals.
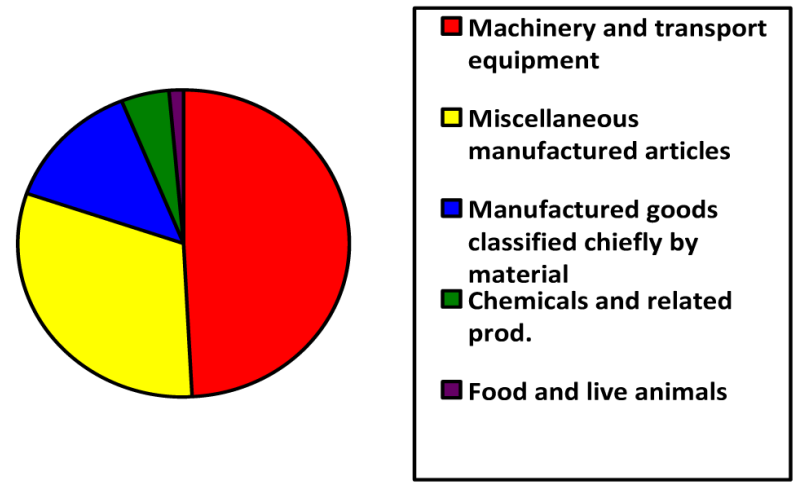

Fig. 4. European Union imports from China in 2014 (SITC sections) (Source: European Commission 2016)

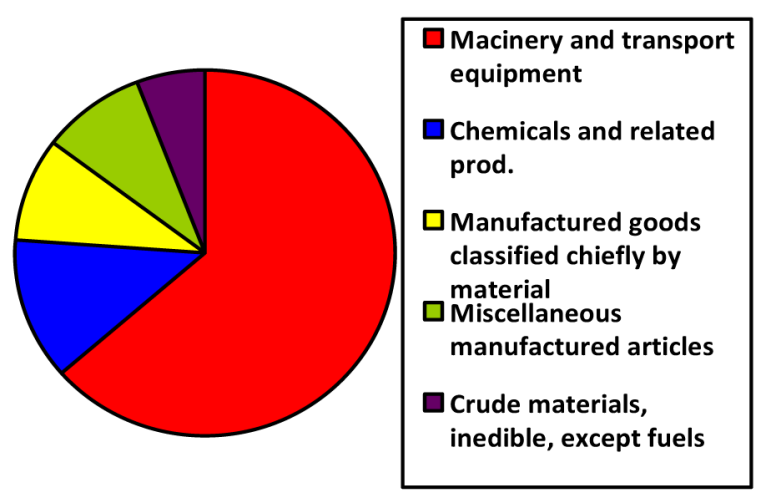

Fig. 5. European Union exports to China in 2014 (SITC sections) (Source: European Commission 2016)

The most important among the most important positions in Chinese imports are agricultural products (only $2 \%$ come from the European exports). In part, this is due to the distance and form of transport. Maritime transport takes 30-40 days, airplane transport is expensive. Agricultural products from the EU enjoy a high credibility and interest of Chinese consumers. Rail transport, in the framework of the NSR, could increase export opportunities and price competitiveness of EU agricultural products. In particular, the countries lying on the route of the railway NSR such as e.g. Poland, Lithuania could benefit from it.

China's major trading partners in the EU are Germany, Netherlands and Great Britain. Due to the geographical location of these countries, it would be particularly desirable in their case to develop the railway branch of the NSR allowing faster access to the markets of these countries. On the 
other hand, Germany is also the largest among the EU countries (and fifth in general) exporter of goods to China, and that is why the acceleration of transport in the direction of China from the point of view of the NSR railway branch seems to be relevant.

\section{Potential benefits from participation in NSR}

Direct benefits from participation in NSR can include:

- Benefits for road transportation companies which will provide links with logistic centres near rail nodes with places of production and industry processing on one side and with recipients of imported goods from the other side.

- In particular European producers of dairy products and especially popular in China whey or milk for babies can expect easier transportation of their goods.

- NSR has a chance to become a tool of multilateral cooperation. For this reason access not only to Chinese market should be taken into account but also to markets of ASEAN, Central Asia and other Asian countries. Indie are also considering participation in this initiative.

- Furthermore in the framework of $16+1$ China is concentrated on increasing import of food from Central and Eastern Europe.

Each of the indicated aspects can be used or neglected if there will be insufficient cooperation between local governments, universities and business representatives. The most important issue is to raise awareness of the importance of the NSR concept and its potential through effective information and knowledge flow.

\section{The New Silk Road as a logistic corridor}

It is important to treat the NSR initiative as a logistic corridor being created, which means integration of different means of transport ensuring seamless continuity of load transport. It involves connecting the lacking elements of the corridor through infrastructural investments, coordination of different transport services and actions aiming at levelling slowdowns resulting from bottle necks such as border inspection. This approach involves building logistic centres, dry ports, airports, which will ensure customs clearance and storage services, creating economic zones, tax incentives encouraging investments along the corridor.
It can be anticipated that the New Silk Road will significantly affect global supply chains through making the time of the transport of goods on the route China-Europe shorter and through expansion of the economic, infrastructural and IT solutions. According to the report of the bank Standard Chartered one of the three main trends influencing the development of the global supply chains will be strengthening the position of China as megatrader as a result of expansion of supply chain through programmes such as NSR (Jha et al. 2015).

All these issues will contribute to the improvement of the economic exchange. Those who will not jump of the bandwagon will stay on the margin of the important economic processes.

For countries on the NJR it is vital whether they will be just a transit territory or whether they will be a place when the trains will be unloaded and reloaded. The question is how European countries can influence their position in this undertaking. First, they should consequently realise the strategy of cooperation with China in this area. In particular it is worth to develop cooperation on regional level especially with the Western provinces of China. Currently often the cooperation is undertaken with different partners from Eastern, coastal provinces. It can be beneficial to start cooperation on a city level with Twin Cities agreements. Launching informative campaigns is also very important. Only those undertakings where synergy of local governments, higher education institutions, research centres and institutes and business is obtained have a chance to succeed. Also effective lobbing and intensive and effective gathering of funds for infrastructural investments is needed. There is also the opportunity to benefit from the Asian Infrastructure Investment Bank and other investments generating high profits like research and development centres.

\section{Challenges of a transport corridor}

NJR, as a transport corridor linking many different countries will face a challenge to become a smoothly operated and profitable corridor. One of the most important challenges will be coordination of transport on stretches of the route with different infrastructure (e.g. three different railway systems Chinese, post-Soviet and European) and dealing with varied legal regulations. NSR will have to fulfil the whole variety of conditions connected among others with interoperability, regulations harmonisation, solving problems with different 


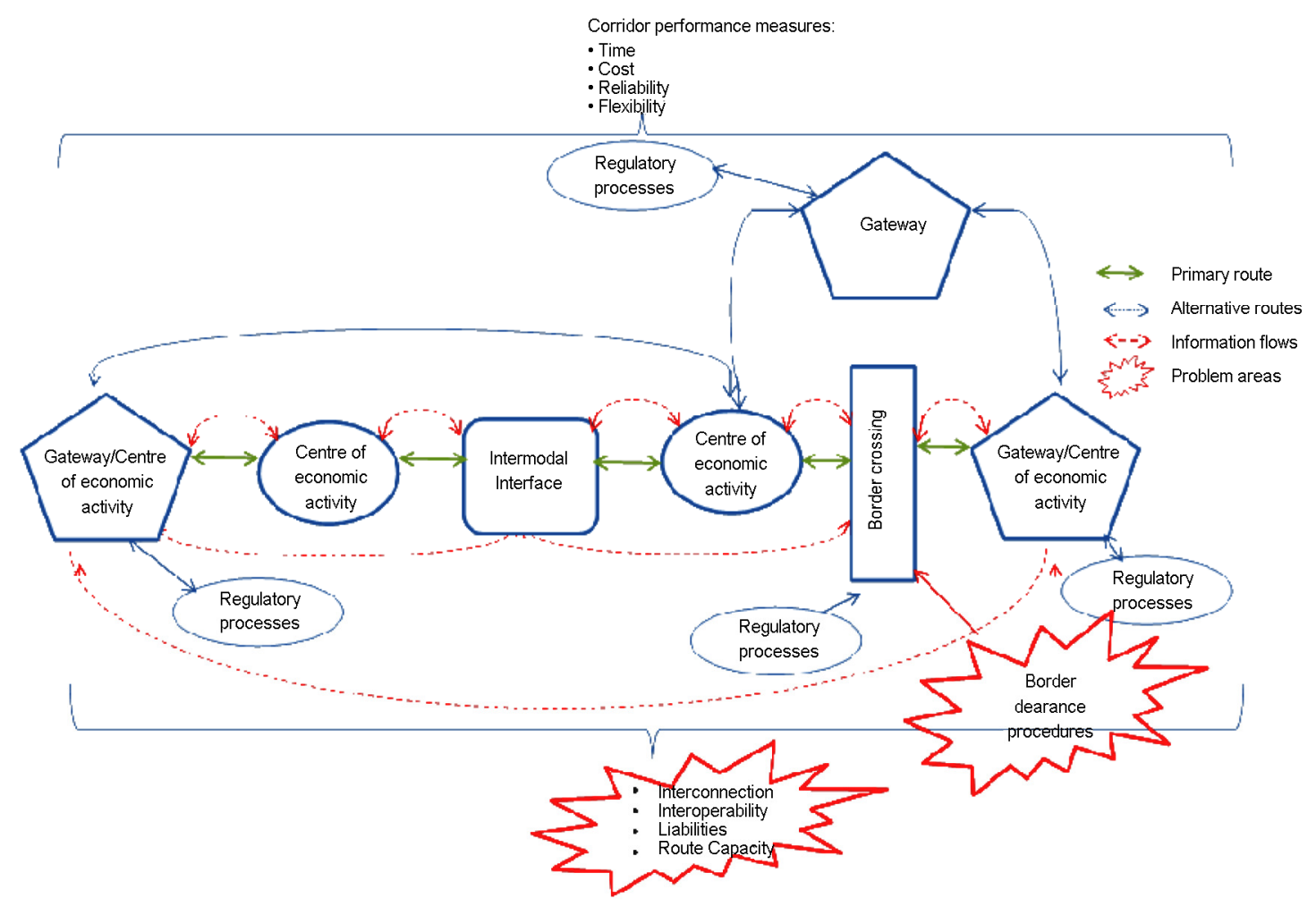

Fig. 6. Challenges of the New Silk Road as a transport corridor

(Source: elaborated by authors on the basis of Arnold 2005)

standards of technical parameters, border clearance procedures, etc. The complexity of the harmonisation of different aspects in the corridor is presented in the Figure 6. It includes a model of a standard transport corridor with centres of economic activity, intermodal interfaces and border crossing with transport routes, regulatory processes and information flows. There are also indicated problems areas which NSR in particular will have to face, such as: interconnection, interoperability, liabilities and route capacity. Another problem area involves border crossing procedures.

The critical issues which may hamper traffic flows along the corridor in the short, medium and longer term include: the lack of cross-border connections; missing links or bottlenecks on other parts of the corridor; absence or insufficient quality of intermodal connections and; infrastructure gaps in urban nodes; discontinuous standards preventing seamless services (European Commission 2015). All these aspects will comprise a big challenge for such a complex undertaking as NSR. At the end there is also a question about assessment of the performance of the corridor which can be measured by time, cost, reliability and flexibility (Arnold 2005). Answering to all these requirements seems to be a great challenge for management.

\section{Conclusions}

The relationship between the development of infrastructure and economic development is obvious and theoretically proven (Carlsson et al. 2013) and empirical (Minerva, Ottaviano 2009). However, the spillover effects that occurs due to new transport infrastructure are not uniform. Many countries and industries through the NSR will develop quickly and dynamically but some may find themselves on the margins of the processes. The overland part of the NSR thread is still a great unknown both in terms of routes and individual logistics solutions. Considering the fact that the major trading partners of China in Europe are Germany, the Netherlands and the United Kingdom, the route should lead from China through Kazakhstan, Russia, Belarus, Poland and further to Germany and other countries of the EU. However, there may occur a number of different branches which will determine the logistics strategy of individual countries and regions in Central and Eastern Europe.

An interesting and important thing is the question of the extent to which the NSR will force the unification of regulations related to the movement of goods through transit countries. Russia's current policy prevents the Polish, Lithuanian and Czech carriers from transiting goods, that is, those who 
until now have been among the leaders. It is to be assumed that the Chinese will not allow such a situation to arise in which any of the transit countries (Russia) is able to limit the flow of goods in selected periods of time. Therefore, the NSR can bring the benefits of unification of procedures and regulations.

The NSR seems to be one of the most influential initiatives of current times that can boost trade and logistics. Especially it can answer the needs to accelerate the transport of goods and materials form remote areas as it is required in the times of global sourcing. Many countries are interested to take part in this endeavour and it is up to their governments how will they use the opportunities. Important factors of competitive advantage are: good infrastructure, infrastructural investments and wellthought promotion of European goods. A significant role should play food products since faster and cheaper transport provides more possibilities in terms of their export. In order to become an effective and profitable corridor NSR has to face many challenges connected with harmonisation of legal, infrastructural and cultural differences.

\section{References}

Arnold, J. 2005. Best practices in corridor management [online]. World Bank, Washington, DC [cited 16 January 2016]. Available from Internet: http://documents.worldbank.org/curated/en/2005/0 2/9795860/best-practices-corridor-management

Baldwin, A. 1993. Domino theory of regionalism. NBER Working Paper No. 4465, Cambridge.

Bonapace, T.; Mikic, M. 2007. Asia-Pacific regionalism quo vadis? Charting the territory for new integration routes, in P. De Lombaerde (Ed.). Multilateralism, regionalism and bilateralism in trade and investment. 2006 World report on regional integration. United Nations University Series on Regionalism. Springer, 75-98.

Carlsson, R.; Otto, A.; Hall, J. W. 2013. The role of infrastructure in macroeconomic growth theories, Civil Engineering and Environmental Systems 30(3-4): 263-273. http://dx.doi.org/10.1080/10286608.2013.866107

Centre for Research and Globalisation. 2015. The New Silk Road, A Chinese-style "New Deal". The Economic and Geopolitical Consequences [online], [cited 25 January 2016]. Available from Internet: http://www.globalresearch.ca/the-new-silk-road-achinese-style-new-deal-the-economic-andgeopolitical-consequences/5466022

El-Agraa, A. M. 1999. Regional integration. Experience, theory, and measurement. New York: Palgrave Macmillan.
Emerson, M.; Vinokurov, E. 2009. Optimisation of Central Asian and Eurasian transcontinental land transport. EUCAm Working paper No. 7.

Embassy of the Republic of Poland in Beijing. 2016. China Economy [online], [cited 15 February 2016]. Available from Internet: http://pekin.msz.gov.pl/pl/wspolpraca_dwustronna /wspolpracagospodarcza/gospodarka_chin/

EUCTP II. 2015. EU-China Trade Project II [online], [cited 5 February 2016]. Available from Internet: http://www.euctp.org/index.php/en/press-andnews.html

European Commission. 2016. European Union, Trade in goods with China [online]. Trade, Directorate General for Trade [cited 25 January 2016]. Available from Internet:

http://trade.ec.europa.eu/doclib/docs/2006/septemb er/tradoc_113366.pdf

European Commission. 2015, Infrastructure - TEN-T Connecting Europe. Corridor studies [online], [cited 25 January 2016]. Available from Internet: http://ec.europa.eu/transport/themes/infrastructure/ ten-t-guidelines/corridors/corridor-studies_en.htm

IMF. 2016. Direction of trade by country [online], [cited 15 January 2016]. Available from Internet: http://data.imf.org/?sk=9d6028d4-f14a-464c-a2f259b2cd424b85\&sId=1454703973993

Informator Ekonomiczny o Krajach Świata [Economic Directory about the Countries of the World] [online] 2016. Ministry of Foreign Affairs Republic of Poland [cited 15 January 2016]. Available from the Internet: http://www.informator ekonomiczny.msz.gov.pl/pl/ (in Polish)

Jha, M.; Amerasinghe, S.; Calverley, J. 2015. Global supply chains: new directions, Special report. Global Research, Standard Chartered.

Lo, Ch. 2015. China's Silk Road strategy, The International Economy Fall 2015: 54, 55, 71.

Minerva, G. A.; Ottaviano, G. I. P. 2009. Endogenous growth theories: agglomeration benefits and transportation costs, in R. Capello, P. Nijkamp (Eds.). Handbook of regional growth and development theories. Cheltenham: Edward Edgar Publishing. http://dx.doi.org/10.4337/9781848445987.00011

Rushton, A.; Croucher, P.; Baker, P. 2010. The handbook of logistics and distribution management. $4^{\text {th }}$ ed. Philadelphia, USA: Kogan Page Limited.

Sahbaz, U. 2014. The Modern Silk Road: one way or another?, On wider Europe, Black Sea Trust for Regional Cooperation, Janurary.

SeaNews Turkey. International Shipping Magazine. 2014.

Starr, F. S.; Cornell, S. E.; Norling, N. 2015. The EU, Central Asia, and the development of continental transport and trade. Central Asia, Caucasus Institute \& Silk Road Studies, Program - A. Joint Transatlantic Research and Policy Canter. 
Vinokurov, E.; Libman, A. 2012. Eurasian integration. Challenges for transcontinental regionalism. London: Palgrave Macmillan.

Williams, A. 2015. EBRD approves China membership application [online]. EBRD [cited 25 January 2016]. Available from Internet:

http://www.ebrd.com/news/2015/ebrd-approveschina-membership-application.html

Yang, J. 2014. Silk Road subsidies undermine rail link [online]. South China Morning Post [cited 15 February 2016]. Available from Internet:

http://www.scmp.com/business/economy/article/16 57286/silk-road-subsidies-undermine-rail-link

Yu, N.; de Jong, M.; Storm, S.; Mi, J. 2013. Spatial spill-over effects of transport infrastructure: evidence from Chinese regions, Journal of Transport Geography 28(April): 56-66.

http://dx.doi.org/10.1016/j.jtrangeo.2012.10.009

The European Union Chamber of Commerce in China [online]. 2015 [cited 5 February 2016]. Available from Internet:

http://www.europeanchamber.com.cn/en/governm ent-updates/11064 